CHAPTER FIVE

\title{
TALES OF A PEASANT REVOLT. TABOOS AND MEMORIES OF 1514 IN HUNGARY
}

\author{
Gabriella Erdélyi
}

In April 1515, an ordinary priest from South Hungary, Clemens Canimich, submitted to Pope Leo X a petition confessing that:

When he [Clemens] was notary of a captain in the army of Thomas, the cardinal-primate and legate of the Holy See, and a crusade was declared [...] against the infidels, out of ignorance and because of the cowardice of the captain, he [Clemens] forged letters in the name of the Hungarian King and the Cardinal which were sent to the Christian faithful so that they should join the fight against the Turks. When many Christians had gathered [...], out of fear of the captain, and since he could not escape the peril of death otherwise, he took part in numerous battles, fights, pillaging, rape, arson and the murder of laymen and even clerics, which they perpetrated against Christians with the captain's troops. ${ }^{1}$

This account is a personal recollection of the events which are usually referred to as the greatest peasant revolt in Hungarian history. At first sight the story as Clemens told it six months after the event seems to be quite incongruous: why and how did he and his captain end up fighting against Christians if they originally summoned an army to take up arms against the Ottoman forces? Yet it made sense, nevertheless. The revolt had developed in response to a call for a crusade in 1514, in which peasants were ordered by pope and king to fight the 'infidel' Ottomans. When the nobility had tried to stop their peasants from leaving home during the busy summer season, the 'rustici cruciati' had turned against their 'infidel' landlords under the leadership of Georgius Dózsa, a Sekler lesser noblemen and soldier in the royal army. The rebellion was supported by many simple priests, who together with a new generation of Observant

\footnotetext{
1 Archivio Poenitentiaria Apostolica, Registra Matrimonialium et Diversorum [hereafter: APA], vol. 59, ff. $72 \mathrm{r}-\mathrm{v}$ (7 April 1515, Bachiensis diocesis). The present study was prepared within the framework of a research project funded by the Hungarian National Research Fund (OTKA-81435) and was supported by the Bolyai fellowship of the Hungarian Academy of Sciences.
} 
Franciscan friars had forged documents and used their preaching as an ideological tool to turn the war against the pagans into a war against the nobility. The uprising was put down in August 1514 by royal forces, and its military leaders were brutally and theatrically executed. ${ }^{2}$

Priest Clemens was one of the thousands of ordinary priests who had joined the peasants, and the first among fifteen who, in the decade up to 1525 , asked for the pope's absolution from the office of the Apostolic Penitentiary for partaking in warfare. By the fifteenth century the Penitentiary had become the chief and the cheapest route to both the salvation of souls and justice on earth in Renaissance Rome, handling violations of canon law ranging from irregular clerical ordinances and marriages to such heinous crimes as murder, sodomy or sacrilege. ${ }^{3}$ The petitioners discussed here, all of them clergymen, needed the papal pardon of their war crimes in order to repair their infringement of canonical rules and regain their clerical status. ${ }^{4}$

Although their stories were clearly influenced both by the procedure of issuing a pardon, which involved the transcription of a petition by a professional proctor who followed a prescribed protocol, and also by the legal demands to which they had to conform, petitioners were unquestionably the authors of their own narratives. While their accounts were intended to be efficacious, they also had to be authentic and truthful since the content was subsequently checked and had to be ratified by witnesses. As documents soliciting the benevolence of the pope, it was also essential that they be formulated very humbly and respectfully. ${ }^{5}$ Additional force

2 On the political and military history of the revolt see: Gábor Barta and Antal FeketeNagy, Parasztháború 1514-ben [Peasant War in 1514] (Budapest: Gondolat, 1973). On its leader, Georgius Dózsa see: 'Georgius Zekeltől Dózsa Györgyig' ['From Georgius Zekel to György Dózsa'], Századok 109 (1975), 63-88. On the manifold relations of the Hungarian province of Observant Franciscans to the revolt see: Jenő Szücs, 'A ferences obszervancia és az 1514. évi parasztháború. Egy kódex tanúsága' ['The Franciscan Observants and the peasant war of 1514'], Levéltári Közlemények 43 (1972), 213-263, and Jenő Szűcs, 'Dózsa parasztháborújának ideológiája' ['The ideology of Dózsa's peasant war'], Valóság (1972) no. $11,12-38$.

3 On the office of the Apostolic Penitentiary see most recently: Kirsi Salonen and Ludwig Schmugge, A sip from the 'Well of Grace'. Medieval texts from the Apostolic Penitentiary (Washington, D.C.: The Catholic University of America Press, 2009).

4 The so-called 'irregularitas ex delicto' was an impediment of priestly ordination. Willibald M. Plöchl, Geschichte des Kirchenrechts, 5 vols. (Vienna and Munich: Verlag Herold, 1955), vol. 2, 290.

${ }^{5}$ In this respect, the scenario of papal pardoning was very similar to the process of royal clemency in sixteenth-century France. Cf. Claude Gauvard, 'Le roi de France et l'opinion publique à l'époque de Charles VI', in Jean-Claude Maire Vigueur-Charles Pietri (eds.), Culture et idéologie dans la genèse de l'État moderne (Paris and Rome: École française de 
could be given to their stories if the supplicant went to Rome to present his petition to the Curia in person. Significantly, all the lesser clerics discussed here were prepared to invest the time and money to undertake such a trip, which suggests that these petitions were primarily a response to the risk of being reported to the diocesan authorities by local competitors; the rivalry among a growing mass of poor clerics for ecclesiastical offices was intense. ${ }^{6}$

Whereas the voices of the victors of the 1514 revolt are quite familiar to historians, these petitions to the pope provide a rare opportunity to hear the voices of the losing side. Research on collective violence often focuses on the motivation of agents and the relation between social status and the willingness to participate in a revolt. ${ }^{7}$ Historical scholarship on the events of 1514 has also been concerned primarily with such issues. ${ }^{8}$ Examining the petitions of the participants, however, provides us with a different perspective and makes it possible to construct a 'bottom up' narrative of the revolt. ${ }^{9}$ The autobiographical narratives constructed after the events enable us to explore the processing of the experience of collective violence. It has been observed that in the twentieth century collective violence tended to be followed by silence, with violent events becoming a taboo subject and only much later followed by a 'wave of speech'. Such a wave of speech can be interpreted either as a form of individual or collective therapy or as an attempt to stake a claim to monopoly over a 'true' version of events. In the verbal battle to establish authority over the

Rome, 1985), 353-366.; Hélène Millet (ed.), Suppliques et requêtes. Gouvernement par la grâce en Occident (XII $-X V^{e}$ siècle) (Rome: École Française de Rome, 2003); Natalie Zemon Davis: Fiction in the archives. Pardon tales and their tellers in sixteenth-century France (Stanford: Stanford University Press, 1987), esp. 57-59.

6 On the market of small benefices and the rivalry among lesser clergy in late-medieval Hungary see Gabriella Erdélyi, Szökött szerzetesek. Erőszak és fiatalok a késő középkorban [Runaway Friars. Violence and Youth in Late Medieval Hungary] (Budapest: Libri, 2011), 97-113, with further literature on the European context.

7 Clark McPhail, The myth of the madding crowd (New York: De Gruyter, 1991).

8 See the chapter on the social and economic standing of the peasantry in Barta and Fekete-Nagy, Parasztháború, 42-59; Ferenc Szakály argues that observant Franciscans joined the peasants because of their own their peasant origins, Mezőváros és reformáció. Tanulmányok a korai magyar polgárosodás történetéhez [Market-town and Reformation. Studies on the early phase of the rise of the burgess class in Hungary] (Budapest: Balassi Kiadó, 1995), 7-32.

9 See the landmark study by John Keegan, The face of battle. A study of Agincourt, Waterloo, and the Somme (London: Penguin, 1976), who first produced a battle narrative focussing on the experiences of common soldiers based on narrative sources. More recently on the culture of total war see Stéphane Audoin-Rouzeau and Annette Becker, 1914-1918: understanding the Great War (London: Profile Books, 2002). 
past, the 'possession' of the dead and claims to martyrdom are essential weapons. ${ }^{10}$

Generally speaking, war memories of the late medieval and early modern period are difficult to get at, due to the limited availability of sources as well as to the different structure of the public sphere. The memories of the Thirty Years War seem to be an exception to this rule, perhaps because in the war's immediate aftermath the events became a major source of contestation between Catholics and Protestants. Eventually, it was the Lutherans who succeeded in monopolizing the commemoration of the war: the annual commemorations turned into a celebration of their victory over their Catholic opponents. By the nineteenth century, however, the military Festkultur that flourished in the multiconfessional cities of Southern Germany was domesticated and turned into a celebration of peace. Framed as a cultural memory the Thirty Years War became a constitutive part of national identity. ${ }^{11}$

The memory of the 1514 revolt developed quite differently. Most recently there has been the rather robust claim that the revolt constitutes 'the unspoken trauma of Hungarian history, which was turned into a taboo right after the event and has remained so ever since.. ${ }^{12}$ Instead of offering a historical-psychological evaluation of the type inherent in this statement, I will apply a sociological approach to cultural trauma by seeking to reconstruct processes of remembering and forgetting after the 1514 peasant revolt. This sociological approach rests on the premise that the events themselves may become traumatic only subsequently, under the impact of narratives forged by historical agents sharing an interest in the making of trauma. ${ }^{13}$ To judge whether this was the case we need to

10 On the phase of repression followed by an outburst of speaking in the aftermath of the 1956 revolution in Hungary, see György Kövér, 'Források, értelmezések, történelmek' ['Sources, interpretations, histories'], in idem (ed.), A felhalmozás ive [The arch of accumulation] (Budapest: Új Mandátum, 2002), 391.

11 Hilmar Sack, Der Krieg in den Köpfen. Die Erinnerung and den Dreißigjährigen Krieg in der deutschen Krisenerfahrung zwischen Julirevolution und deutschem Krieg (Berlin: Duncker \& Humblot, 2008). I use the distinction between communicative and cultural memory introduced by Jan Assmann, Das kulturelle Gedächtnis. Schrift, Erinnerung und politische Identität in frühen Hochkulturen (München: Verlag C.H. Beck, 2007), 48-55.

12 Katalin Péter, A reformáció. Kényszer vagy választás? [The Reformation: coercion or free choice?] (Budapest: Európa, 2004), 73.

13 Jeffrey C. Alexander, 'Toward a theory of cultural trauma', in Jeffrey C. Alexander et al. (eds.), Cultural trauma and collective identity (Berkeley, CA: University of California Press, 2004), 1-30; Wulf Kansteiner, 'Finding meaning in memory. A methodological critique of collective memory studies', History and Theory 41 (2002), 179-197, esp. 186-187. 
ask who were the agents of trauma (or the dramatisation of memory) and what was at stake for them.

In the first part of my paper, I will briefly outline the dynamics of the memory war that followed the dramatic events of the revolt and address the question of how personal memory and identity formation interacted with public stories in petitions. In what ways did individual and collective memories shape representations of the violence? In the second part, I will sketch the later memories of the uprising in early modern cultural memory in Hungary and abroad.

\section{Rebels, Traitors, Infidels, and Barbarians}

The petition of priest Clemens makes no mention of the revolt, instead isolating and portraying the events as the outcome of a personal exchange between him and the cardinal:

Since, however, Holy Father, the petitioner was warned by the cardinal to desist from his acts [that is: illegal recruiting], he was excommunicated for his obstinacy, $[\ldots]$ which he regretted and regrets now. [...] He therefore asks to be absolved for homicide and other excesses and sins in return for due penitence and also to be suspended from divine services for a time. He would like though to keep his priestly office and benefices under the condition that he exercises penitence in front of the cardinal and humbly requests his forgiveness.

As we have seen, Clemens' effort to conceal the uprising and his role in it involves an incongruous story, starting with a proclamation of a crusade against the Ottomans and ending with Christians killing Christians. It is so peculiar that I suspect priest Clemens was one of the illegal preachers of the crusade who organised the uprising. His dissimulation may reflect the defensive reorganisation of his personal identity under the impact of the new social realities, which he must have perceived to be menacing. He composed his story in the aftermath of the uprising in a very tense situation dominated by anger and fear. Inevitably, his version of events was grounded in the brutal execution of the peasant leaders and the decree of the National Diet ordering the search for and execution of all rebels, who were called 'public malefactors', the murderers of noblemen and the rapists of virgins. ${ }^{14}$ Characterizing the reaction of the frightened nobility,

14 Corpus Juris Hungarici. Magyar Törvénytár 1000-1526, ed. Dezső Márkus (Budapest: Franklin Társulat, 1899), anno 1514/art. no. 4, 13, 14, 33. 
one sixteenth-century chronicler of the events noted that 'the Hungarian landlords behaved ruthlessly with the poor, oppressed the crusaders in many different ways' ${ }^{15}$

However, petitions from subsequent years reveal that the rebel memories of the revolt were suppressed only temporarily. As the bloody wave of noble revenge came to an end and the anticipated mass executions did not ensue, former rebels could resurface and present themselves publicly in the emerging memory war over the monopoly of legitimate violence and just war. We can witness the fabrication of the rebel myths penned by lesser priests from villages and market-towns situated in the heartland of the rebellion. In the dramatic story of the priest Benedictus of Nagyhatvan, written in 1519, the opposing protagonists are the crusaders and the nobility:

When a crusade against the infidels was declared in Hungary , and he himself took up the cross with many others, a conflict and quarrel erupted between the nobles and the crusaders, in the course of which the nobles attacked the crusaders. To defend themselves, he needed to take up arms too with his fellow crusaders. ${ }^{16}$

By attacking the crusaders as they were preparing to fight the natural enemies of Christianity, the nobles had taken the place of the Ottomans and had themselves become infidelis. This chain of thought must have appeared familiar in the papal Curia since it borrowed its central concepts from the papal bull declaring the crusade against the Turks. Both Pope Leo $X$ and the crusaders spoke of a 'holy' and 'praiseworthy crusade'. ${ }^{17}$ The pope had promised the remission of all sins for participants and supporters of the war while threatening absentees and those obstructing the war with excommunication on earth and eternal damnation in hell. The peasants could thus interpret the revolt as the realisation of the papal curse and replace the infidelis Turks with the infidelis landlords. ${ }^{18}$ Of course, this version of events countermanded the plot in the official stories of the ruling elite, in which the label infidelis had connotations of rebellion and treason and is used instead to as an attribute for the peasantry. ${ }^{19}$

15 1504-1566 Memoria Rerum, ed. József Bessenyei (Budapest: Magyar Helikon, 1981), 17.

16 APA vol. 64, ff. 111r-v (19 April 1523).

17 Monumenta rusticorum in Hungaria rebellium anno MDXIV (Publicationes Archivi Nationalis Hungarici II. Fontes 12), ed. A. Fekete Nagy - V. Kenéz - L. Solymosi - G. Érszegi (Budapest: Akadémiai Kiadó, 1979), 47.

18 Szűcs, 'Dózsa parasztháborújának ideológiája', 12-38.

19 See the exhaustive analysis concerning the characterization of the rebellious peasant in the different genres and sources produced in the sixteenth century by Gábor 
The voices of the verbal battle emerged in the geographical centres of the revolt (Abaúj and Zemplén Counties, the border region of Békés and Bihar Counties, the area around the city of Csanád, Bodrog and Bács Counties). The parties disputed who had been the aggressor, who had had to defend themselves, and which party had been (more) ruthless. On both sides, the dramatisation of events climaxed in a conspiracy theory.

After he had recruited many crusaders against the enemies of the Christian faith, and when they were ready for launching this honourable expeditionsuddenly, at the instigation of the enemy of humankind - the nobles attacked the crusaders. When the crusaders realised the betrayal of the nobility, they bravely started to defend themselves in order to save their lives.

This quote is taken from one of the rebel narratives by Nicolaus of Bihar, the chantry-priest of the parish church of the market-town of Bihar. ${ }^{20}$ In this account, penned in 1523 , the conflict is no longer attributed to the discord between the crusaders and the nobility but rather to the treachery of the latter. A very different conspiracy theory is elaborated in the counternarrative of a noble participant, Dionisious Kascach in 1525:

When his most reverend eminence, Cardinal Thomas, was sent as legate to Hungary in order to launch a crusade with royal permission and apostolic authority, some ignorant rebels and troublemakers rebelled against him and his followers, and took up the cross in order to kill his eminence and his followers. [...] Among them was the royal captain, Georgius Székely, too. [...] When he [the captain] discovered the fraud, he turned at once against the aggressors and rebels. ${ }^{21}$

The story of Dionisius is modelled on the plot developed in a humanist epic poem about a revolt in the cardinal's court: Stephanus Taurinus, Stauromachia id est Cruciatorum Servile Bellum, Vienna, 1519. In this Moravian humanist tale, events which had originally occurred in various locations and had very complex causes were all subsumed in one easily comprehensible conspiracy theory. It presents the crusaders as determined from the outset to exterminate the entire nobility under the pretext of the crusade led by a fraudulent and power-thirsty leader, Dózsa. ${ }^{22}$ The idea is repeated

Klaniczay, 'Images and designations for rebellious peasants in late medieval Hungary', in Balázs Nagy and Marcell Sebők (eds.), The man of many devices, who wandered full many ways ... Festschrift in Honor of János M. Bak (Budapest: CEU Press, 1999), 115-127.

20 APA vol. 7o, ff. 358v-359r (2 April 1523, Waradiensis diocesis). Bihar is today Biharia, in Romania.

21 APA vol. 73, ff. 157r-58r (3 January 1525, Wesprimiensis diocesis).

22 Stephanus Taurinus Olomucensis, Stauromachia id est cruciatorum servile bellum. Servilis belli pannonici libri V, ed. Ladislaus Juhász (Budapest: Egyetemi Nyomda, 1944). 
in the autobiographical account by another cleric, Gregorius Koppándi, from the landed nobility of Transylvania, who wrote in $15^{20}$ :

Many peasants gathered under the pretext of a crusade in the Kingdom of Hungary and revolted against the nobility with the intention to destroy them totally. Then, on royal orders he took up arms with the barons and nobles to destroy this huge peasant army. After they had defeated the peasants, he imprisoned forty peasants by the law of war, and considering the brutality the peasants had committed against nobles and clergymen, he made a peasant sit on a trunk and nailed his genitals and his buttocks to the trunk with iron nails, so that by punishing him, others would be terrified and deterred. ${ }^{23}$

The narrator obviously derived a strange pleasure from the detailed account which he volunteered here of the torturing of the peasant. Within the context of the memory war such details may seem surprising since they run counter to usual practice. When petitioners claimed in their formal written statements that they had committed legitimate violence, they refrained from any explicit, let alone literal, depiction of precisely what they had done. Instead, the legitimacy of their act was underpinned by brief references to the brutality of the enemy. The powerful, on their part, accounted for their bloody retribution simply with reference to their defence of the patria and their right to wage war. ${ }^{24}$ Our noble cleric was more talkative: it was possible for him to speak about his own extreme violence. The volubility of Koppándi is comprehensible when viewed in its contemporary context. In the late medieval culture of honour and the ritual processes of conflict negotiation which involved rites of both violence and law, there was much room for extreme but legitimate violence. ${ }^{25}$

In Hungarian: Taurinus, Paraszti háború [Peasants' War], trans. László Geréb (Budapest: Magyar Helikon, 1972). Taurinus belonged to the entourage of Cardinal Bakócz but later became the vicar of Franciscus Várdai, Bishop of Transylvania, who was the vice-legate entrusted by Bakócz to gather the army for the crusade in Transylvania. See also Várdai's petition to the pope after the revolt: SPA vol. 59, fol. 424r (August 1515).

23 APA vol. 66, ff. 52r-v (28 March 1520, Transylvaniensis diocesis). Gregorius probably describes one of the last battles fought at the castle of Bihar (July 1514) with the army of Pál Tomori, castellan of Fogaras (Fặgặras in Romania), who was his patron.

24 For example Franciscus More, canon of Vác argued that 'alias atrocissima rabie illius rusticane thyrannidis in Regno Hungarie vigente' he fought 'pro domestica libertate conservanda', APA vol. 63, ff. 74r-v (1518); Franciscus Várdai, bishop of Transylvania: 'conflictibus et bellis iustis pro defensione patrie [...] armatus interfuit'. APA vol. 59, f. $424 \mathrm{r}(1515)$.

25 See the anthropological approaches towards violence, both interpersonal and collective, as well as the studies of legal anthropology: Daniel Lord Smail, The consumption of justice. Emotions, publicity, and legal culture in Marseille, 1264-1423 (Ithaca, N.Y-London: 
Koppándi depicted his violence as an act of law enforcement by arguing that he took part in a defensive war under royal orders and that he captured and punished the rebels in accordance with what was common wartime practice. In a similar vein, in subsequent petitions to the pope, those fighting a just war against the infidel Turks readily and extensively recounted their savage deeds. ${ }^{26}$ The sexual torture, mutilation and dehumanisation of the enemy served to exert power over the body of the rebels and, in this way, symbolically restore the social order. ${ }^{27}$ Rather than being brutal, Koppándi was being just. Furthermore, his story is a textual representation of the late medieval theatre of horror where public execution and the cruelties of warfare were the regulated and accepted sites of representing the body in pain. ${ }^{28}$ We read the naturalistic portrayal of the execution of the 'peasant king' Dózsa in the humanist epos: 'The lymph burst forth abundantly from his broken skull, his brain bubbling out through his ears, mouth, and nose'. ${ }^{29}$ In 1514 a pamphlet entitled 'The Hungarians' crusade and the extreme cruelty committed on both sides' appeared in Rome. ${ }^{30}$ In its pages, the pious peasants who deemed themselves 'followers of the cross' are transformed into 'savage pagans' after they collectively rape noblewomen, but the climax of the story is the 'brutal, but well-deserved' death of the peasant leaders:

The leaders were immediately taken, and their naked bodies tied with irons to long stakes and burned alive on fire, some of them put on the cross, others skinned and left alive for some days. Some were quartered and fed to the dogs. ${ }^{31}$

Cornell University Press, 2003); Stuart Carroll, Cultures of violence. Interpersonal violence in historical perspective (London: Palgrave Macmillan, 2007).

${ }^{26}$ As did the Transylvanian nobleman Petrus Berekszói: once 'exercitum penes mare contra infideles haberet dictus exponens in dicto exercitu fuit et ibidem quamplures turcos $[\ldots]$ viros et mulieres cum parvulis manu propria interfecit, quandam etiam mulierem puerum lactantem manu propria interfecit et puerum etiam mortuum exinde credit'. APA vol. 3, ff. 397v-98r (1452).

27 Natalie Zemon Davis, 'The Rites of Violence' in her, Society and culture in early modern France (Stanford: Stanford University Press, 1975), 152-188.

${ }^{28}$ Péter Tóth G. 'A fájdalom metaforái. A testi fájdalom, a kegyetlenség és a vértanúság látványa a kora újkori Magyarországon' ['Metaphors of pain. The scene of bodily pain, brutality and martyrdom in early modern Hungary'], in Éva Pócs (ed.), Mikrokozmoszmakrokozmosz. Vallásetnológiai fogalmak tudományközi megközelítésben [MicrocosmMacrocosm. Concepts of religious ethnology in an interdisciplinary approach] (Budapest: Balassi Kiadó, 2001), 319-372, with further literature.

29 Taurinus, Paraszti háború, 65.

30 Janus Vitalis Panormitanus, De Ungarorum Cruciata facto anno 1514. et de infanda saevitia utrinque patrata, Roma 1514 in Monumenta rusticorum, 242-245.

31 Ibid., 245 . 
The staging of their torture had a moral, spiritual and aesthetic value in a communicative space distinct from the memory war. Moreover, reports such as these were trying to meet the increasing demand of an international public for news and entertainment. ${ }^{32} \mathrm{~A}$ pamphlet series published in German cities as the events unfolded during 1514 ended with an image of the peasant king crowned with a red-hot iron crown, being roasted on his throne and eaten by his fellows while listening to a $T e$ Deum laudamus. ${ }^{33}$ The author promised a second issue to update readers on the continuing fight on the battlefield, but this never appeared, as-we might guess - the appetite for horror of the readership was already well satisfied.

With regard to the Hungarian battle of words, we have seen how participants on either side, rebels and the powerful alike, fabricated conspiracy theories, transforming very varied individual motives and chaotic happenings into a linear and logical sequence of events. A process of smoothing personal and public memories into basic stories that made normative claims and aimed to shape the experience of those in the present and future alike seems to have been well underway, but it was still tied to the original setting of events. The accounts of those participants who remained outsiders to the subsequent memory war, however, have a very different narrative structure. Since they were not influenced by retrospective schemes of explanation and communal mythmaking, they remained far closer to the horizon of authentic individual experience of chaos and brutality. This can be observed in the story of Stephanus Mening, a cleric from Transylvania, who, four years after the events, did not even mention the uprising and used a biographical frame instead:

He was schoolmaster in the village of St. Ladislaus, when, together with other villagers living under the landlord Antonius Polner, he was forced by the threats and orders of the late Johannes Székely, and took up arms against the city of Segesvár. He did not intend to hurt, mutilate or kill anybody, and was unaware of the intentions of Johannes Székely, who broke

32 Péter Tóth G. 'A lator teste és a lator test. A bűnösség kultúrája a kora újkori Magyarországon és a büntetés-emlékeztetés problémája (vázlat)' ['The body of the rouge and the rouge body. The culture of sin in early modern Hungary and punishments as rites of memory. A draft'] Korall 5-6 (2001), 141-162, there 150.

33 Zeckel Jorg, Die auffrur so geschehen ist im Vngerlandt mit dem creutzern vnnd auch darbey wie man der creutzer haubtman hat gefangen vnnd getoedt [1514], in Monumenta rusticorum, no. 227; Paul Freedman also stresses the barbarous manner of Dózsa's execution which also astounded contemporaries. Paul Freedman, Images of the Medieval Peasant (Stanford: Stanford University Press, 1999), 269-270. 
into the house of the said landlord living in the city and killed him and his wife. On his road home, however, Johannes was murdered by the friends and kin of Antonius, in which he did not participate in any way. ${ }^{34}$

This well-known account of the uprising was modelled on the universal theme of feuding neighbours and on murder stories that never mention war at all. ${ }^{35}$ Four years later Mening again recounted his experiences through the lens of a direct participant: he said that he had been drifting with the crowd and had no idea whatsoever about what was happening to him. This may be realistic in the sense articulated by some theorists of collective violence, who argue that the majority are in the dark about what is going on around them and cannot foresee its possible consequences. ${ }^{36}$

There is no space here to elaborate on other examples, but such accounts by neutral 'outsiders' permit some generalisations about their narrative patterns. ${ }^{37}$ First, representations of violence in accounts of individuals who were not involved in the uprising differ from those in the public stories told in the context of the memory war. Outsiders remembered themselves participating in collective violence but denied having killed anyone personally, which suggests that it was possible to preserve the coherence of personal identity at the expense of making a taboo of interpersonal violence (a memory practice that has also been observed in individual memories of World War I). ${ }^{38}$ Interpersonal violence, however, resurfaced in the memory war, in which competing group identities were at stake and when there were political arguments to justify the use of extreme violence even outside the context of the normal suspension of everyday norms in wartime.

Given the barbarity of the enemy, war is frequently idealised and presented publicly as a fight of civilisation against barbarity. ${ }^{39}$ In the bloodthirsty 'public history' of the pamphlets, however, both parties were rendered as extremely cruel. Secondly, the centres of the memory war overlap with the intellectual and military centres of the revolt. Interestingly, these were exactly the same regions that in earlier decades had

\footnotetext{
${ }^{34}$ APA vol. 63, ff. 34r-v (1518).

35 See the royal donation letter from 1520 . Monumenta rusticorum, no. 383 .

36 This is called the irrational theory of collective violence, see McPhail, The myth.

37 Benedictus de Pellerd, presbyter Quinqeecclesiensis diocesis (APA vol. 63, ff. 38r-39r, 1518); Emericus Wolconz scolaris Zagrabiensis diocesis, (vol. 66, ff. 24v-25r, 1520); Georgius de Bodon, frater ordinis predicatorum Quinqueecclesiensis diocesis, (vol. 62, ff. $57 \mathrm{v}-58 \mathrm{r}$, 1517).

38 Audoin, Rouzeau and Becker, 1914-1918, 39.

39 For the modern analogy see ibid., 116.
} 
produced the bulk of long-distance pilgrims and where the evangelical teachings in following decades met with a quick and intense response. ${ }^{40}$ These paradoxical coincidences can most probably be explained, as Jenő Szücs has proposed, with reference to the presence of Observant Franciscans, whose friaries show a similar geographical distribution. ${ }^{41}$ This finding, in turn, suggests that the popular public sphere of the late fifteenth and the early sixteenth centuries was strongly shaped by the activity and preaching of these Observant Franciscan friars, which ranged from exhortations to take up the cross to anti-noble sermons and the spreading of spiritualist, messianic ideas.

\section{Dózsa, the Martyr}

In the $15^{20 s,}$ it was in the same places, and simultaneous with the memory war about the 1514 Revolt, that the first investigative campaigns against 'heretics' began. It is remarkable and surprising that during these inquests, the charge of heresy was never reinforced by identifying the accused as rebels, as Katalin Péter has noted. ${ }^{42}$ This decoupling is all the more remarkable since during the time of the bloody retribution for the peasant revolt of 1525 in Germany, the figure of the rebel and the Lutheran were totally fused. For example, a Würzburg pastor was put in prison by a landowner in 1525 because 'he preached the tenets of Luther and a rebellion' and was therefore considered a dangerous person 'liable to make the ordinary folk rebel in the future'. ${ }^{43}$ From the perspective of Catholic and Lutheran authorities alike, the German Lutheran was considered to be an insubordinate subject.

In Hungary, by contrast, the identities of rebel and Lutheran were not coterminous because the revolt was not instrumentalised in the construction of Catholic and Protestant identities. Instead of the figure of the

40 The regions in question are the Abaúj and Zemplén counties in the North-East; Csanád, Békés and Bihar counties in the Great Plain; and Bács-Bodrog in the South along the Danube. Cf. Enikő Csukovits, Középkori magyar zarándokok [Medieval Hungarian Pilgrims] (Budapest: MTA TTI, 2003), 188, and Szűcs Jenő, 'Ferences ellenzéki áramlat a magyar parasztháború és reformáció hátterében' ['Franciscan opposition movement in the background of the Hungarian peasant revolt and the Reformation'], Irodalomtörténeti Közlemények 78 (1974), 409-435, 426.

41 Szücs, 'A ferences obszervancia', 243-244.

42 Péter, A reformáció, 72-73.

43 Robert W. Scribner and Tom Scott (eds.), The German Peasants' War. A history in documents (London and New Jersey: Humanities Press International, 1991), document no. 149. 
rebel, the extreme brutality of the death of the 'peasant king' Dózsa later came to epitomise memories of the revolt. By that time, they were already disconnected from the original sites where the events had occurred. Thus, Stephanus Istvánffy, an early seventeenth-century chronicler at the court of the Habsburg king, introduced his lengthy description of the execution as follows:

I shudder at the thought of enumerating the horrible, extreme and unprecedented punishments of these miserable people. Since even if they deserved this terrible torture and death, it would nevertheless have rather suited pious Christians to subdue such a cruel massacre by piety and compassion. ${ }^{44}$

Looking at it from a century's distance, the experience of the theatre of horror of public executions seems to have undergone a profound shift. The image of the peasant leader sitting silently on a burning throne with a red-hot crown on his head and watching the execution of his brother while awaiting being quartered, displayed publicly, and finally devoured by his starved fellow-rebels continued to be reproduced in word and image (figures 2 and 3 ). It seems that this image persisted in the consciousness of the aristocracy and nobility since they were familiar with historical chronicles of the revolt and occasionally commissioned such texts. ${ }^{45}$ The memory of the revolt could thus be used to mobilise the paralyzed nobility in times of crisis. The aristocratic political leader, Palatine Nicolaus Esterházy (1625-1645) exhorted the nobility in 1632 with the following words:

You should remember the peasants' attack in the time of king Ladislaus, which caused huge bloodshed and the country's devastation. Those who have ever read the chronicles about it, will possibly know [...] that we will have to follow the example of John Szapolyai [who put down the revolt and ordered the executions] when acting against the peasants, not letting the traitors go and searching after them all possible ways. ${ }^{46}$

44 Nicolaus Istvánffy, Historiarum de rebus Ungaricis libri XXXIV (Cologne, 1622). Istvánffy Miklós magyarok dolgairól írt históriája Tállyai Pál XVII. századi forditásában [The history of Nicolaus Istvánffy in the XVIIth century translation of Pál Tállyai], ed. Péter Benits, vol. 1. (Budapest: Balassi, 2001), 141-142.

45 István Monok, A müvelt arisztokrata. A magyarországi fónemesség olvasmányai a XVI-XVII. században [The erudite aristocrat. The readings of the Hungarian aristocracy in the XVI-XVII centuries] (Budapest-Eger: Kossuth, 2012), passim.

46 Letter of Esterházy to the nobility of Sáros county, $3^{1}$ March 1632. Published in János Reizner, 'A Császár-féle Felső-Magyarországi 1631-1632. évi pórlázadás okmánytára' ['The documents of the Peasant Revolt led by Császár in 1631-1632'] Történelmi Tár 11 (1888), 128. 


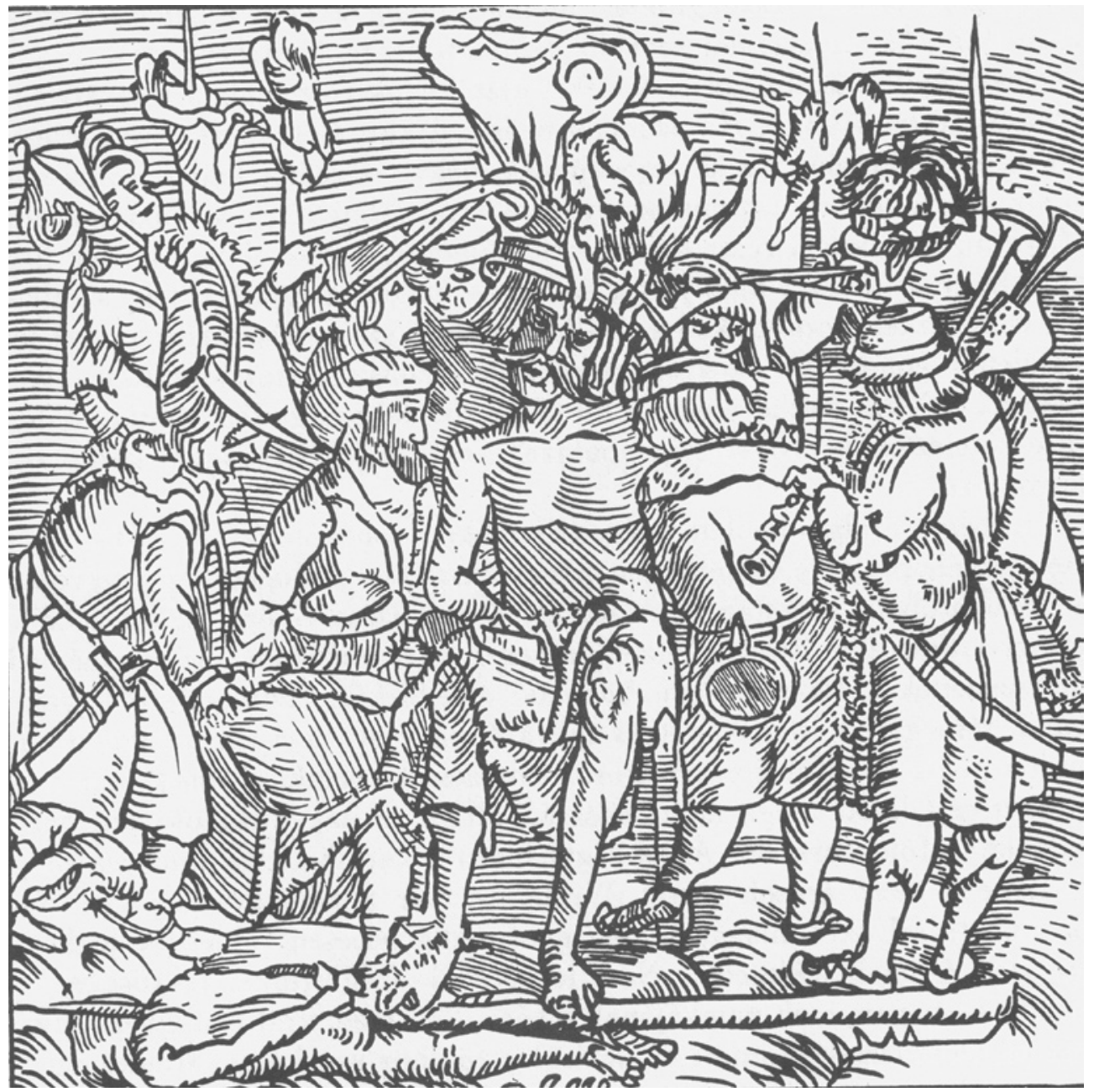

Fig. 2. The execution of Dózsa on the front page of Stephanus Taurinus, Stauromachia (Vindobonae, 1519), With the permission of the National Széchényi Library (Budapest), Régi Nyomtatványok Tára (Collection of Old Prints). 

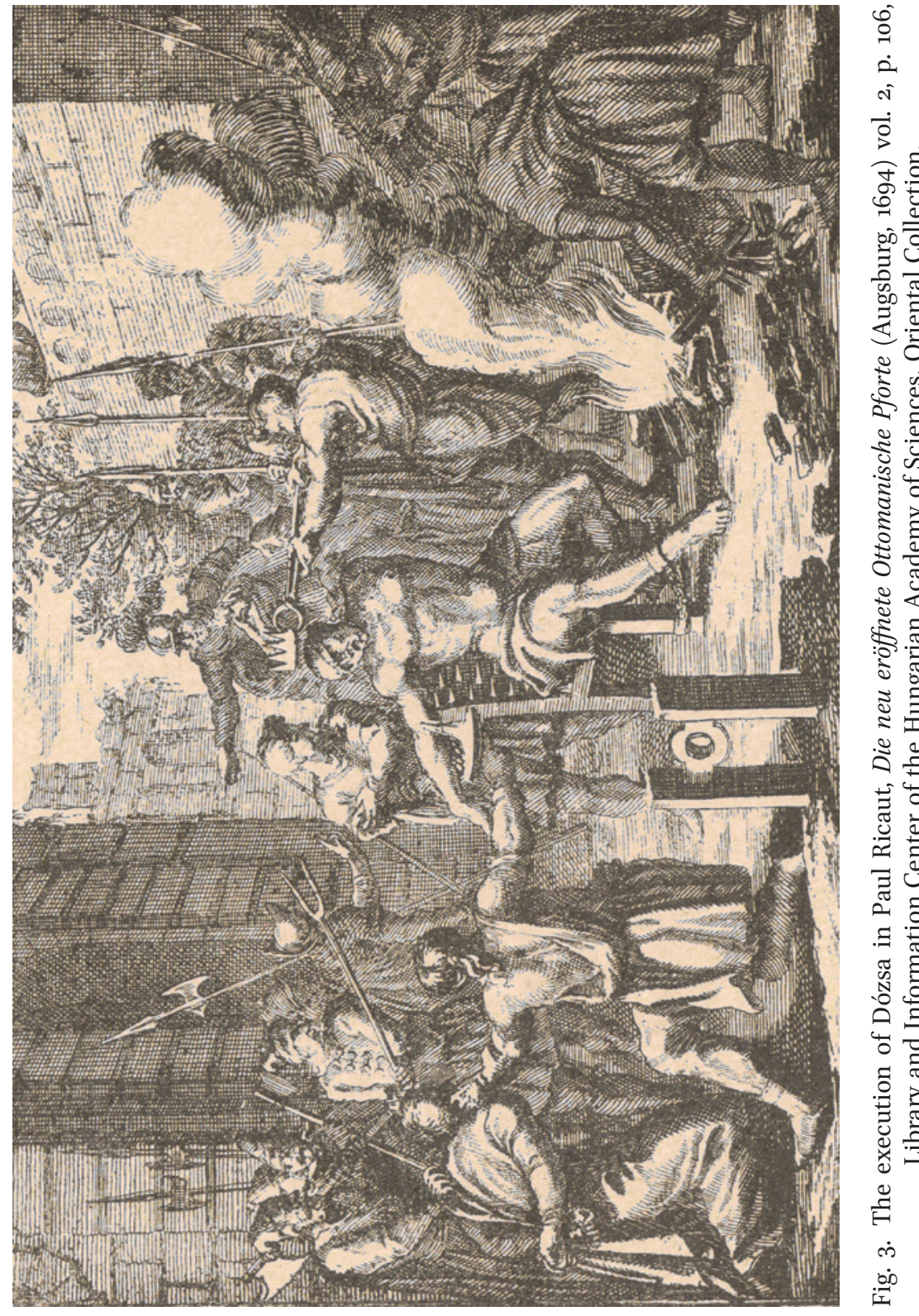
Esterházy was a man of his word. The leader of the 1632 peasant revolt, Peter Császár was tortured and his body quartered. ${ }^{47}$ From the sixteenth to the eighteenth century the ritual retributions for peasant revolts and other political rebellions became public occasions for remembering $1514 .{ }^{48}$ The public execution of early modern rebels reminded spectators of the sacralised death of Dózsa staging the passion of Christ and the ritual of holy communion. I would go so far as to speculate that the nobility's perceptions included even the Dózsa-Christ analogue. For them, the sufferings of the peasant rebel must have represented the deserved penance for the sins of his fellows, whose redemption in the afterlife must have seemed natural for them as well. The contemporary chronicler, Georgius Szerémi, a native of the region where the execution happened, recorded that Georgius Dózsa soon after his death was venerated as the 'second St George of Macedonia, the martyr' and the place of his execution became a site of pilgrimage. ${ }^{49}$ The above-mentioned chronicler Istvánffy commented on the execution of the leader Matej Gubec of the Croatian peasant revolt in 1572:

tearing dreadfully with burning pliers and crowned with a burning ironcrown and finally cut into four in the manner of thieves, he received the due punishment for his crime and usurpation of the royal title; he was punished with such severity, so that the elderly, who are still alive, would remember with horror the unfortunate assault of Georgius Sekler Dózsa who had wanted to extirpate the nobility. ${ }^{50}$

\section{Conclusions}

The ruling elite, who had learned to fear the peasants in 1514, engineered the staging of the dramatic memorialisation of the Revolt and then of its stigmatisation in subsequent centuries. Public executions were designed to deter crime and to legitimate power by reminding people of the consequences of rebellion and making them recoil from any repetition. We do not know how ordinary folk responded. If early modern spectators

\footnotetext{
47 László Makkai, A felsôtiszavidéki parasztfelkelés 1631-1632 [The peasant uprising in the Upper-Tisza region, 1631-1632] (Budapest: Művelt Nép, 1954).

48 For further examples see Tóth, 'A fájdalom metaforái', 352-353, 359-360.

49 Georgius Sirmiensis, De Perditione Regni Hungariae, trans. into Hungarian by László Juhász (Monumenta Hungarica V), (Budapest: Magyar Helikon, 1961), 68. The association of Christ's martyrdom with Dózsa's death was suggested by István Nemeskürty in 1983, Önfia vágta sebét [Wounded by his own son] (Budapest: Magvető, 1983), 164-166.

50 Istvánffy Miklós magyarok dolgairól, 485.
} 
remembered, identified with and experienced the pain when it was displayed on stage, as several scholars have suggested, they may have felt that this suffering contributed to their purification and salvation. ${ }^{51}$ In terms of the psychological concepts current today, the repeated recollection and staging of such painful events would have hindered mental healing and we would expect the pre-modern practice of public execution as a commemorative ritual to have worsened any collective traumas. But if 'nations can [freely] repress [and forget] with psychological impunity', 52 as Iwona Irwin-Zarecka has recently argued, we may have to conclude that the self-image of early modern society in Hungary was in fact stabilised by the cultivation in text, image and ritual of the martyr Dózsa and his crown of thorns. ${ }^{53}$

51 See for example Valentin Groebner, Defaced. The visual cultures of violence in the late middle ages (New York: Zone Books, 2004), 99-104.

${ }^{52}$ Iwona Irwin-Zarecka, Frames of remembrance. The dynamics of collective memory (New Brunswick, NJ: Transaction, 1994), 116.

${ }^{53}$ For this definition of cultural memory see Jan Assmann, 'Collective memory and cultural identity', New German Critique 65 (1995), 132. 